Review of

ECONOMICS

and

INSTITUTIONS

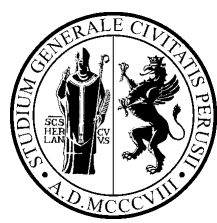

www.rei.unipg.it

\title{
Introduction to the REI Special Issue: "The Role of History, Biogeography, and Institutions for Comparative Development"
}

\author{
Stelios Michalopoulos \\ Andrea F. Presbitero ${ }^{\boxplus}$ \\ Brown University and NBER International Monetary Fund and MoFiR
}

\begin{abstract}
The importance of history, culture, and biogeography in shaping current institutions and the long-run process of economic development is the subject of an important and growing field of research, attracting prominent scholars from different backgrounds. This special issue brings together contributions that investigate both theoretically and empirically the potential mechanisms that mediate the link between institutional and economic development.
\end{abstract}

JEL classification: N10, N50, 010

Keywords: Comparative development, Institutions, Economic History

Corresponding author. Address: International Monetary Fund, 700 19th Street, N.W., Washington, D.C. 20431 (Phone: +1 202 623989. Email: APresbitero@imf.org).

\section{Recommended Citation}

Michalopoulos, S., Presbitero, A.F. (2014). Introduction to the REI Special Issue: "The Role of History, Biogeography, and Institutions for Comparative Development". Review of Economics and Institutions, 5(2), Article 1. doi: 10.5202/rei.v5i2.167.

Retrieved from http://www.rei.unipg.it/rei/article/view/167 


\section{Introduction}

The importance of history, culture, and biogeography in shaping current institutions and the long-run process of economic development is the subject of an important and growing field of research, bringing together prominent scholars from different backgrounds (see Diamond 1997, Acemoglu and Johnson 2005, Herbst 2000, and Gallup and Sachs 2001 among others).

While understanding the forces shaping the evolution of economic disparities across time and space has been one of the key questions in economics, earlier strands of the literature mainly focused on establishing the primacy of one factor over the others in the process of development. A first wave of cross-country studies involved testing alternative hypotheses of the drivers of economic performance looking at the relative importance of institutions, legal origins and human capital in explaining differences in income per capita (see Acemoglu et al. 2001, 2002, La Porta et al. 1997, 1998, and Glaeser et al. 2004 among others). Starting with Diamond (1997), who highlights the crucial role of geography in affecting long-run development via the differential timing of the transition to agriculture, another wave of studies switched attention to deep-rooted factors of comparative development uncovering (pre)historic forces influencing contemporary income levels. Galor and Moav (2002) and Galor and Michalopoulos (2012), for example, argue that the Neolithic Revolution triggered an evolutionary process that affected comparative development. Easterly et al. (2010) find that very old history of technology adoption is a significant determinant of today's economic outcomes. Others are investigating the role of genetics, including Spolaore and Wacziarg (2009) and Ashraf and Galor (2013), who explore the role of genetic distance and genetic diversity, respectively, in shaping comparative development.

Yet despite the implementation of ingenious instrumental-variable approaches employed in the cross-country literature, omitted variables and estimate stability remain major concerns (see La Porta et al. 2008, and Nunn 2012, among others). As a result, the literature is now gradually moving from a cross-country setting to a more nuanced, often within-country, exploration of the underlying forces, exploiting quasi natural experiments and shifting the attention to non-state actors including ethnic and religious groups and specific historical accidents (colonial policies, for example) in shaping the process of development, see Dell (2010), Michalopoulos and Papaioannou (2014), Michalopoulos and Papaioannou (2013), Nunn and Wantchekon (2011).

This special issue contributes to this latest strand of literature by investigating both theoretically and empirically the potential mechanisms that mediate the link between institutional and economic development.

On the theoretical front, Kaiser and Roumasset offer a framework for conceptualizing the emergence of centralized political hierarchies in natural- 
resource-based economies. The intuition is the following. In early stages of development, population density is low and natural resources relatively abundant. In this stage, land and fishing grounds hold relatively low value implying low opportunities for rent extraction and, hence, no basis for hierarchical societies. Nevertheless, as population grows (labor to natural resources ratio increases), the value of land and fishing grounds increase relative to labor. This intensification sets the stage for the endogenous appearance of hierarchical institutional structures which engage in rent extraction via the control of natural resources. The key benefit of centralized authorities lies in the observation that as population pressure mounts, leading to resource depletion, it also raises the gains from trade across districts. If such potential gains are large enough to warrant the increased governance costs of further centralization of authority, then more complex, hierarchical structures are likely to emerge. The authors produce a detailed account on the coevolution of population, resource use and institutional change in the context of Hawaii consistent with the proposed theory.

The control over scarce natural resources is also in the heart of the analysis of Guenzi and Rossi, who consider the historical experience of the 'Dogana delle Pecore', an institution introduced during the XV century in the Kingdom of Naples by Alfonso I, to mediate tensions between farmers and shepherds regarding the control of agricultural land. The authors discuss the introduction and functioning of an innovative institution, which was a key driver of regional development and trade in Southern Italy. The 'Dogana' guaranteed the temporary migration of millions of sheep and thousand of shepherds for pasture over 500 kilometers. The coordination issues emerged as it was necessary to find the right shares of grazing land and land for cultivation, and allocate each flock the right amount of grazing land. The number of actors involved, the volume of production and the resulting trade required the presence of an effective institution enforced by a centralized authority. The 'Dogana' was able to provide the right incentives to landowners and cattle owners, eliminating disputes regarding land control.

The literature documenting the persistence of comparative development beyond the country level has been hampered by the sparsity of historical economic indicators at a regional level. To circumvent this issue existing empirical studies have focused on individual countries where historical measures are available. This is the path followed by Basso. The author focuses on Spain and documents a so-far-neglected link between ownership structure and literacy across Spanish districts in the late 19th century. In particular, he establishes that the ownership rate of livestock used in agriculture is a robust correlate of district-level males literacy rates. In order to shed light on what livestock ownership captures, Basso moves to the province level where more economic indicators are available and documents that inequality in livestock ownership is a good proxy of inequality in land ownership. 
Armed with this observation he asks whether the observed variation in literacy rates may be attributed more to demand or supply considerations. Across Spanish provinces the positive correlation between ownership and literacy rates is stronger and more robust than the negative association between ownership inequality and literacy rates. In other words, literacy rates seem to be driven by the presence of numerous livestock/land owners (irrespective of the size of holdings) rather than the presence of few owners of large estates blocking the emergence of education-promoting institutions.

The presence of detailed historical data allows for a comprehensive account of the factors shaping regional development. However, such explorations are limited to currently developed nations whereas such archival data are hardly available for regions within the currently less developed countries. This is the value-added of Christopoulos, Mimis and Siourounis study. In particular, the authors introduce a novel, time-varying measure of economic activity across regions. This is captured by per capita $\mathrm{CO} 2$ emissions which are available at various time intervals over the last 200 years. After discussing the advantages and pitfalls of this new proxy of development they show that in the context of Africa both historical as well as contemporary $\mathrm{CO} 2$ emissions correlate strongly with existing measures of pre-colonial and current economic activity across ethnic regions. Having established that variation in $\mathrm{CO} 2$ emissions is a plausible proxy of regional development over time they test whether there is cross-sectional income convergence across historical African ethnic homelands between 1850 and 2005. The focus on ethnic regions is motivated by recent research that highlights the importance of ethnic-specific traits in shaping within-country variation in economic performance in Africa. The authors utilize both parametric and non-parametric tests of cross-sectional income distribution and establish that African ethnic homelands exhibit two persistent steady states: one very low and one medium-to-high. This study besides offering a new measure of regional development also contributes to the literature on income convergence across ethnically diverse societies.

Finally, the study by Farla adds to the lively debate on the role of the financial sector in the real economy and the intense process of financial deepening that occurs nowadays in many developing countries. Understanding which kind of institutions are more conducive to financial deepening is an important question. While the profession debates how excessive development of the financial sector may lead to financial instability, hamper economic growth and change income distribution, there is a widespread consensus that the development of well-functioning and competitive credit markets in developing and emerging economies can promote access to financial services, foster sustainable economic growth and reduce poverty. The contribution by Farla could be read within this framework, as it tries to identify which kind of institutions are more complementary to the expansion of credit markets across countries. The paper builds on previous work 
by Acemoglu and Johnson (2005) and shows that property rights protection is not the only institutional feature associated with financial deepening. In contrast, institutions governing contractual arrangements and competition crucially matter, as they mitigate informational asymmetries and reduce rents in credit markets. These results support the idea that promoting competition would stimulate the development of financial markets, leading to beneficial real effects. One key lesson from this analysis is that empirical researchers should look inside the "black box" of institutional measures, devoting attention to the details of specific institutional aspects and measures in order to distinguish those features of the institutional environment that are more relevant for different aspects of economic growth. 


\section{References}

Acemoglu, D., Johnson, S., 2005. Unbundling Institutions. Journal of Political Economy 113, 949-995. doi:10.1086/432166

Acemoglu, D., Johnson, S., Robinson, J.A., 2001. The Colonial Origins of Comparative Development: An Empirical Investigation. American Economic Review 91, 1369-1401. doi:10.1257/aer.91.5.1369

Acemoglu, D., Johnson, S., Robinson, J.A., 2002. Reversal of Fortune: Geography and Institutions in the Making of the Modern World Income Distribution. Quarterly Journal of Economics 107, 1231-1294. doi:10.1162/003355302320935025

Ashraf, Q., Galor, O., 2013. The Out of Africa Hypothesis, Human Genetic Diversity, and Comparative Economic Development. American Economic Review 103, 1-46. doi:10.1257/aer.103.1.1

Dell, M., 2010. The Persistent Effects of Peru's Mining Mita. Econometrica $78,839-857$.

Diamond, J., 1997. Guns, Germs, and Steel. The Fates of Human Societies. W.W. Norton and Co, New York, NY.

Easterly, W., Comin, D., Gong, E., 2010. Was the Wealth of Nations Determined in 1000bc? American Economic Journal-Macroeconomics 2, 65-97. doi:10.1257/mac.2.3.65

Gallup, J.L., Sachs, J.D., 2001. The Economic Burden of Malaria. The American Journal of Tropical Medicine and Hygiene 64, 85-96.

Galor, O., Michalopoulos, S., 2012. Evolution and the Growth Process: Natural Selection of Entrepreneurial Traits. Journal of Economic Theory 147, 759-780. doi:10.1016/j.jet.2011.04.005

Galor, O., Moav, O., 2002. Natural Selection and the Origin of Economic Growth. Quarterly Journal of Economics 117, 1133- 1191. doi:10.1162/003355302320935007

Glaeser, E.L., La Porta, R., De Silanes, F.L., Shleifer, A., 2004. Do Institutions Cause Growth? Journal of Economic Growth 9, 271-303. doi:10.1023/B:JOEG.0000038933.16398.ed

Herbst, J., 2000. States and Power in Africa. Princeton University Press, Princeton, NJ.

La Porta, R., Lopez-De-Silanes, F., Shleifer, A., 2008 The Economic Consequences of Legal Origins. Journal of Economic Literature 46, 285-332. doi:10.1257/jel.46.2.285 
La Porta, R., Lopez-De-Silanes, F., Shleifer, A., Vishny, R., 1997. Legal Determinants of External Finance. Journal of Finance 52, 1131-1150. doi:10.1111/j.1540-6261.1997.tb02727.x

La Porta, R., Lopez-De-Silanes, F., Shleifer, A., Vishny, R., 1998. Law and Finance. Journal of Political Economy 106, 1113-1155. doi:10.1086/250042

Michalopoulos, S., Papaioannou, E., 2013. Pre-colonial Ethnic Institutions and Contemporary African Development. Econometrica 81, 113-152. doi:10.3982/ECTA9613

Michalopoulos, S., Papaioannou, E., 2014. National Institutions and Subnational Development in Africa. Quarterly Journal of Economics 129, 151-213. doi:10.1093/qje/qjt029

Nunn, N., 2012. Culture and the Historical Process. Economic History of Developing Regions 27, 108-126. doi:10.1080/20780389.2012.664864

Nunn, N., Wantchekon, L., 2011. The Slave Trade and the Origins of Mistrust in Africa. American Economic Review 101, 3221-3252. doi:10.1257/aer.101.7.3221

Spolaore, E., Wacziarg, R., 2009. The Diffusion of Development. Quarterly Journal of Economics 124, 469-529. doi:10.1162/ qjec.2009.124.2.469 